\section{artelogie}

\section{Artelogie}

Recherche sur les arts, le patrimoine et la littérature de I'Amérique latine

15 | 2020

Latin American networks: Synchronicities, Contacts and Divergences.

\title{
Conceptualism in Transit: Horacio Zabala's Maps
}

\author{
Luiza Mader Paladino
}

\section{OpenEdition}

\section{Journals}

\section{Electronic version}

URL: http://journals.openedition.org/artelogie/4851

DOI: $10.4000 /$ artelogie.4851

ISSN: 2115-6395

\section{Publisher}

Association ESCAL

\section{Electronic reference}

Luiza Mader Paladino, «Conceptualism in Transit: Horacio Zabala's Maps », Artelogie [Online], 15 | 2020, Online since 07 January 2019, connection on 05 August 2020. URL : http://

journals.openedition.org/artelogie/4851; DOI : https://doi.org/10.4000/artelogie.4851

This text was automatically generated on 5 August 2020 .

Association ESCAL 


\title{
Conceptualism in Transit: Horacio Zabala's Maps
}

\author{
Luiza Mader Paladino
}

\section{Introduction}

1 In line with the theme of this dossier-Latin American networks, synchronicities, contacts, and differences-this article focuses on the cartographic works by artist Horacio Zabala and their relationship to the institutional network created between São Paulo and Buenos Aires during the seventies. I will reflect on this transnational connection through two specific lines of research: first the study of exhibitions, and second the trajectories of certain museums and cultural institutions. Regarding the first, the history of exhibitions is a fertile field because it sheds light not only on the dynamics of the art system but also on singular works and artists and how they have been evaluated. Regarding the second, I will examine the institutional strategies adopted by the Museu de Arte Contemporânea da Universidade de São Paulo and by the Centro de Arte y Comunicación to promote an unprecedented regional network of experimental art. This exchange forged an important channel of dialogue between Latin American artists, among them Zabala. Investigating and comparing the two institutions' management models helps us understand their points of convergence. It sheds light on theoretical affinities and, above all, on the expansion of artistic exchanges in a period marked by political turbulence.

\section{Conceptualisms in transit}

2 In "Dezessete questões sobre a arte" ("Seventeen questions about art"), Horacio Zabala asked the question: Does [art] offer maximum possibilities with minimal resources? (ZABALA, 2015, p.214). This question was key to the aesthetic and conceptual program the artist and architect developed throughout the seventies. The question suggested the reduction of formal and material resources in keeping with the political and 
economic reality of Latin American countries. The result of that reduction, however, could-at least potentially-be far-reaching, and include expanding the channels of circulation and exhibition beyond traditional artistic institutions. During that period, Zabala's production was closely associated with the Centro de Arte y Comunicación (CAYC) in Buenos Aires. At the same time, through the mail art circuit he established ties with the Museu de Arte Contemporânea da Universidade de São (MAC USP).

3 MAC USP, a public institution run by the Universidade de São Paulo, was directed by Walter Zanini from the year of its launch, in 1963, until 1978. The Museum had a broad program and little financial support. Its mission was dialectical in that it intended to build a collection of modern art while also holding a series of retrospective exhibitions and supporting contemporary production (FREIRE, 2013: p.28). In the seventies, MAC USP became part of a broad international communication network driven by mail art. Art increasingly sought to go beyond the work conceived as a unique object. Instead, it attempted to connect groups of artists, cooperatives, and other alternative forms of interchange that operated well outside the logic of the market.

4 Meanwhile, CAYC, a private entity created by art critic and entrepreneur Jorge Glusberg in 1968 and directed by him subsequently, ushered in a new cultural panorama in Buenos Aires. In its formational phase, the Center stimulated the link between art and technology. In the following years, it set out to associate its founding theoretical and artistic precepts with conceptual poetics grounded in the Latin American context while also pursuing the internationalization of local art. To that end, Glusberg created the Grupo de los Trece, ${ }^{1}$ of which Zabala formed part. The Grupo de los Trece was a collective of thirteen artists created on the methodological foundations of Polish theater director Jerzy Grotowski's "poor theater." Grotowski's postulates went beyond the barriers of traditional theatre. They became a conceptual and aesthetic point of reference for the artistic avant-garde of the sixties and seventies that envisioned art as a means of knowledge and participation bound to the social sphere (GLUSBERG, 1985: p. 129). Zabala's "maximum possibilities with minimal resources"-a crucial premise of his work-was linked to Grotowski's idea of an interdisciplinary laboratory. A creative act that, like "poor theater," made use of a bare minimum of resources was akin to Zabala's critical and artistic thinking and to the cornerstones of CAYC's practices starting in 1972, with the exhibition CAYC al Aire Libre. Arte e Ideología (Outdoor CAYC. Art and Ideology) in plaza Roberto Arlt in Buenos Aires. ${ }^{3}$

5 MAC USP and CAYC were two major institutional hubs that advocated experimental practices in South America (PALADINO, 2015: p.159). Their similar programs stimulated the production and exhibition of proposals of a conceptual nature often considered subversive in a context marked by censorship and violent dictatorship. The network connecting the São Paulo museum and CAYC in Buenos Aires contributed to expanding "a transnational dialogical territory" that led to, among other things, exchanges between artists, exhibitions, invitations to colloquia and, especially, a "dialogue sensitive to the Latin American cultural problem." ${ }^{4}$

6 The first project that brought the Argentine conceptual artists in the Grupo de los Trece and other conceptual artists close to that group to MAC USP was the Prospectiva 74 exhibition in 1974. The exhibition organized by Spanish artist Julio Plaza and Walter Zanini was part of an extensive international communication network inspired by mail art. The mail art poetics, "arising from the urgent need to replace existing structures at 
the international level"-as Zanini had written-was, starting in the seventies, fundamental to connecting artists from around the world. ${ }^{5}$

7 Hundreds of works, many of them based on conceptual practices and new media, were sent to the Museum via post: postcards, alternative publications, artists' books, maps, diagrams, visual poetry, photographs, installation projects, documentation of performances, among others. Words and texts were a privileged means of expansion and a communication strategy, as well as-indeed mostly-a potential link between different territories (FREIRE, 2015: p.47). On the international mail art circuit, Zabala commented:

The network of connections between artists and intellectuals was very important in countries with horrendous and violent dictatorships [...], in other words, in countries where censorship was an unbearable everyday reality. Besides direct action against power, that is, political struggle, the only way to connect and engage in a free interchange over distance was through the post. The post was a means not only to avoid censorship, but also to investigate new artistic languages (ZABALA, 2015: p.221).

At the invitation of Walter Zanini, Zabala sent to the Prospectiva 74 exhibition the work Integração de linguagens poéticas experimentais com investigações sociais e econômicas (Integration of Experimental Poetic Languages with Social and Economic Investigation), a series of cartographic interventions.

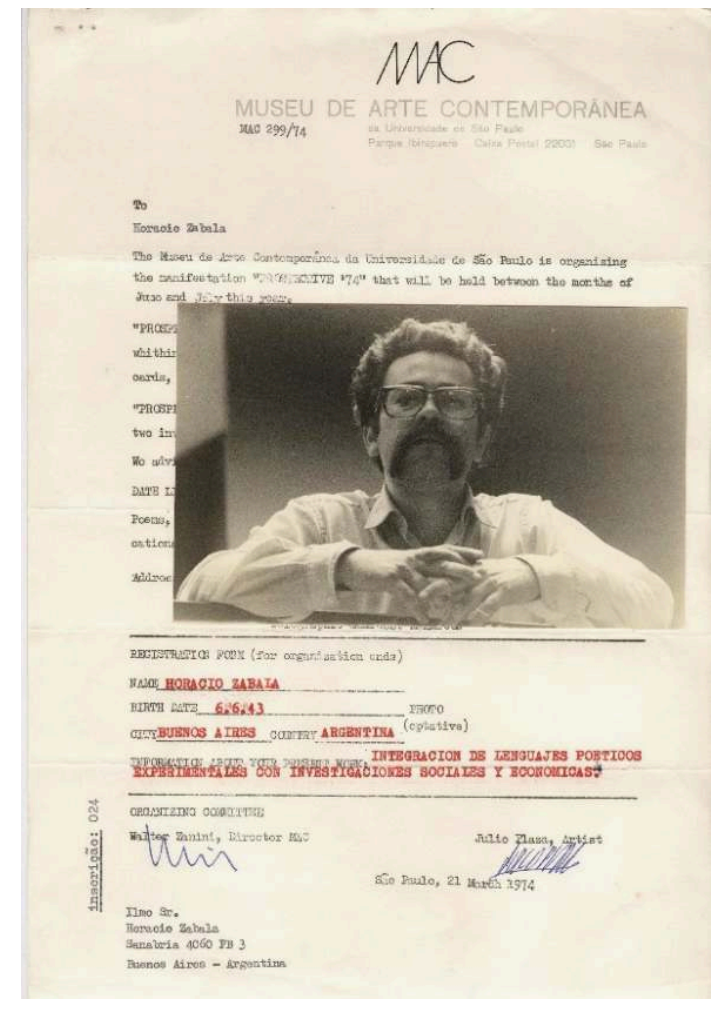

Image 1 - Zabala's registration form for the exhibition Prospectiva 74, 1974

Work: Integração de linguagens poéticas experimentais com investigações sociais e económicas 
9 As, arguably, its title could suggests, the work proposes the use of minimal visual resource-the map-to yield vast social and economic effect. The artist appropriated cheap world maps of the sort used in schools and turned them into a disfigured geography. An architect's method with its rigor and mathematical precision was consistent with Zabala's imagery: maps, floor plans of prisons and other architecture works as reduced models of reality. Zabala treated the maps like a kind of ready-made. ${ }^{6}$ As an object appropriated from material reality, the ready-made, here the maps, is ambiguous. These ready-mades ceased to be functional and informative. Furthermore, Zabala did not choose these maps and floor plans because of their formal qualities. They were, rather, selected for their very inexpressiveness (ZABALA, 2015: p.224). The ready-made-which, of course, transforms an everyday object into a work of art-ends up triggering a series of questions in traditional exhibition environments and, in so doing, redefines the value of artistic and institutional systems, opening up new possibilities for creation in exhibition venues.
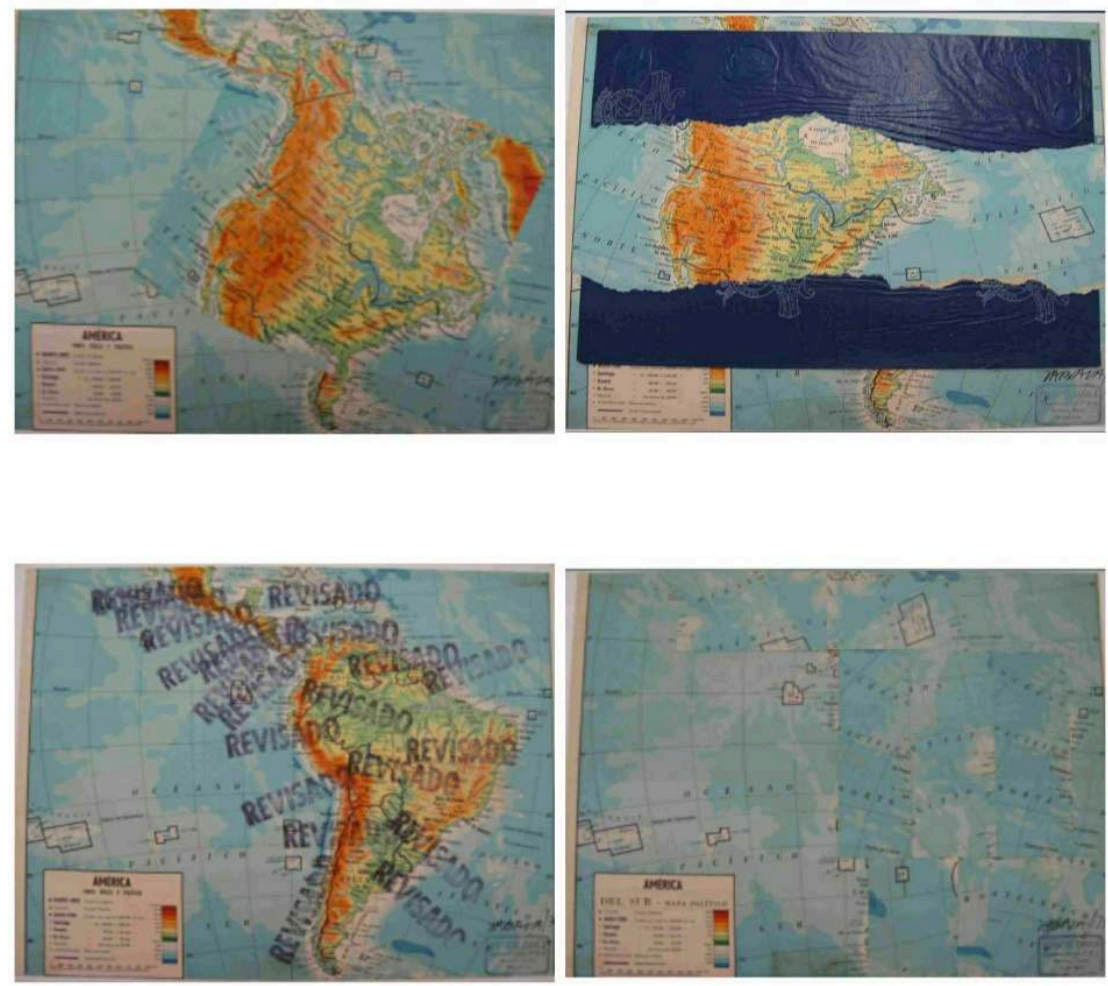

Image 2 - Horacio Zabala,

Integração de linguagens poéticas experimentais com investigações sociais e económica, 1974

Stamp, typewriting and typography on envelope, adhesive tape, carbon paper and stamp on printed map. (Detail), $152,5 \times 75 \mathrm{~cm}$. MAC USP Collection

In the series of ten maps sent to MAC USP, the artist operated directly on the image of the Latin American region, using rubber stamps, cutouts, and collages. In one of the works, he shuffled borders by gluing a piece of the map of the United States and Canada on top of South America. In another, the continent was again covered by a collage of 
various fragments of the Atlantic and Pacific oceans, changing the spatial logic with new frontiers in a mosaic of glued cutouts. Three blank purchase receipts were pasted on Latin America, suggesting that the continent itself was for sale. A rubber stamp of the word "revisado" was plastered over Latin America. Here the stamp, an item found in public offices, took on a new connotation, opening the way for different poetic possibilities. That word appeared a number of times in the same image, reinforcing its reverberation through graphic and semantic accumulation.

11 Zabala used the stamp as an aesthetic and political device in other cartographic works as well, creating his own typology. The maps with the revisado and censurado (censored) stamps across Latin America warned of the repression and violation of human rights rife in the region. Zabala, like many artists, made wide use of the relationship between image and word during this period. They created their own lexicons, using a single word to encompass many ideas. The word itself would, then, become a sort of collective call to action. Revisar-Censurar became a kind of signature for the artist, a reference to a tactical use of anonymity as a means to enable circulation through controlled territories.

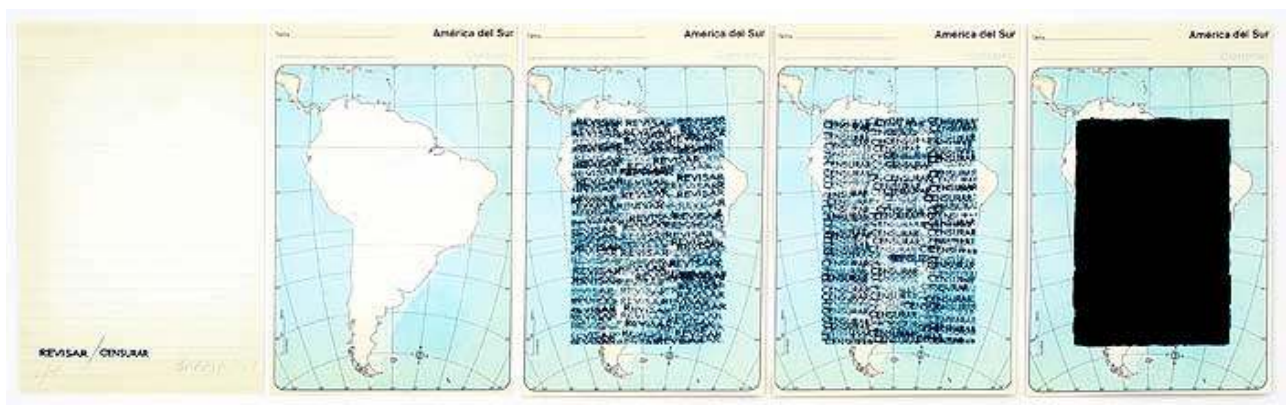

Image 3 - Horacio Zabala

Review - Censor, 1974

Postage stamp and stamp on map

$25 \times 80 \mathrm{~cm}$

12 Zabala's method consisted of appropriating a technical and rational standard of supposedly neutral spatial representation to dismantle the places selected, distorting the reduced reality on a sheet of paper. The artist's social and economic research showed the power maps have exercised throughout history in order to, among other things, legitimize and further colonialism. The divvying up of occupied countries has been a constant in the exercise of power in the history of war and invasion.

13 These socio-aesthetic operations also indicated the mechanisms of power behind the political disputes evident in maps. The choice of the Latin American territory as a privileged place for poetic interference was wholly deliberate. For the artist's generation, Latin America was a symbol of cultural integration and political identity as opposed to the space of a North American imperialist offensive. This ideal of continental union would be renewed after the Cuban Revolution in 1959 as a real alternative to the capitalist model. 

its policy towards its neighbors. Programs geared to strengthening dialogue as part of the "Good Neighborhood Policy" changed in the face of the perceived Communist threat in the region. The strategy to neutralize revolutionary movements looked to new allies. It turned away from "vulnerable politicians [and] representatives of the new industrial bourgeoisies linked to the modernizing project [favoring instead] the military actors and dictatorships that dominated the Latin American political system during the sixties" (GIUNTA, 2008: p.301). country by country, was being undermined by the military, with the blatant support of the United States government. The artist's operation of placing the map of North America directly over the map of Latin America, and his use of carbon paper to cover up entire countries or parts of them, warned of the history of censorship, interference on the part of the northern section of the continent and dependence on the part of its Latin side. After all, the United States called itself "America" and its citizens "Americans," and the other part of America was relegated to the term "Latinos." ${ }^{8}$

Other members of the Grupo de los Trece participated in the São Paulo exhibition, among them Juan Carlos Romero and Luis Pazos. The Prospectiva 74's call for submissions made use of a system of invitations and nominations, and Jorge Glusberg proposed Pazos. In a letter he sent to the director of MAC USP, Pazos commented on the work he sent to the exhibition:

My work revolves around "action art," that is, works where I am both the material and its representation, here a medieval ritual performed by myself (the central figure) and dolls on a stage set. [...] I wish you the greatest success with the show. Best Regards. ${ }^{9}$

The "action art"-also known as attitude art-that the artist mentions was geared to more active viewer participation and to joining art and life through multiple, as opposed to unique, works. This time, the artist sent six photographs of La Ciudad poseída por los Demonios (The City Possessed by Devils) a performance held at CAYC that same year. In his work of action art, Pazos used the body as poetic and political territory, bringing to the fore the brutal reality of the military regime.

18 Juan Carlos Romero sent in a series of nine offset prints and a woodcut entitled, together, Violência ${ }^{10}$ that he had worked on in Buenos Aires over the previous years. The work consisted of multimedia research on the many meanings of the word violence. One year earlier, Romero had exhibited an installation of the same name at CAYC that lay bare the conflicts between the space of art and the political urgencies of the day by addressing violence from the perspectives of psychoanalysis, literature, journalism, and philosophy. He printed posters with the definition of violence according to the Bible, Che Guevara, and Mao Zedong. For the work, the artist also appropriated sensationalist newspaper articles that reported scandals and violent stories.

19 Another Argentine featured in the Prospectiva 74 exhibition was Edgardo Antonio Vigo. Although not part of the Grupo de los Trece, he participated in several exhibitions at CAYC. An artist, poet, and editor, Vigo was a precursor to conceptual art and experimental poetry in Argentina, as well as a point of reference for a number of artists, among them Luis Pazos and Horacio Zabala. He was the editor of Diagonal Cero and Hexágono 71, publications dedicated to visual poetry and experimental art. As the editor, Vigo proposed changes to those magazines' format to turn them into a kind of 
magazine-object where the reader could choose the way to handle and interact with the graphic piece. Vigo was an active participant in the mail art network. He was close to Walter Zanini, as some of the letters they exchanged evidence. In one of them, Vigo writes:

Dear friend, Thank you very much for your letter of 1-75 confirming receipt of my work. I am so glad you enjoyed it. [...] I have chosen, and grown accustomed to, correspondence not only as a means of communication but also-in my recent works-as an artistic medium: I have been swept away by ART BY CORRESPONDENCE. ${ }^{11}$

As an artist-editor, Vigo organized those two publications (Diagonal Cero and Hexagono) and circulated them not only as magazines but also as artists' books in logic quite different from the art market's. Mail art or postal art, as the artist defined it, represented artistic decentralization; messages could be sent to any corner of the planet. How a work of mail art circulated was generally determined by the network of artists who, after receiving a letter of invitation, would send their works in a previously established format and number (FREIRE, 2015: p. 27). MAC USP joined this international network as a possible place to house and support this alternative form of production. Prospectiva 74 represented the culmination of this broad dialogue between artists from different parts of the world. As Zanini put it in the introduction to the exhibition catalog:

The international repercussion of PROSPECTIVA 74 , as evidenced by the participation of artists from so many countries, opens up, in my view, a path that had seemed blocked in Brazil. Brazilian artists and artists from other countries can now engage in a deep dialogue. MAC has tirelessly sought to facilitate this contact with the world in its own exhibitions, as well as through activities undertaken abroad (ZANINI, exhib. cat. 1974).

Prospectiva 74 , as Zanini made clear, forged a fundamental channel of dialogue between Latin American artists. It also strengthened relations between the Museum and CAYC. The next year, Horacio Zabala helped expand exchange between the two countries by proposing an exhibition entitled Confrontación to be held at MAC USP. As its title suggests, the Argentine artist's main idea was to produce an environment of debate and of intellectual and artistic exchange between four Brazilian artists and four Argentine artists, among them Juan Bercetche, Romero, Vigo, and Zabala himself. Along with the exhibition, a "catalog/book" would be published featuring photographs, documentation, and theoretical texts. Intended to be educational, this material would, Zabala held, be an "exchange of ideas on the Latin American avant-garde housed at MAC." Although the plan did not materialize, the exchange of letters on it reveals the Museum as a space open to new languages, above all to conceptual practices met with askance in traditional exhibition venues. It also demonstrates the importance of the MAC USP as a point of resistance to the establishment and of support for alternative ideas and emerging artists.

This exchange was based on the expansion of a political strain of conceptual art in Latin America. Much conceptual art and action art of the period pursued two fundamental aims: to redefine art and the artistic object; and to strategically discuss the social and economic reality facing the region.

In a stance that understands the limits of the art object in an ethical and political field of action, Horacio Zabala wrote, art is defined by the function it performs in society. 
Neither making art nor the results of that making is autonomous: art depends on what is not art" (ZABALA, cat. exp., 1972). Art was no longer autonomous, and this emerging production showed that the meaning of a work no longer resided in the work itself. As such, art and life were brought together as mutually defining. Art of this sort understood the work of art as an agent or catalyst of social and political change. Art was now a tool capable of revealing power relations in a novel aesthetic agenda.

International conceptual art arose as an avant-garde criticism of the legacy of modernism, specifically of the imperative of visuality and artistic autonomy. If the modernist discourse neutralized the art object-above all painting-by inserting it in a linear fiction that culminated with the discovery of its own support-the twodimensional surface-a critical reexamination of that autonomous notion of art sought to contaminate it with other political, social, and aesthetic discourses. In this sense, Latin American artists' growing engagement with a devastating panorama of de facto governments was an attempt to place a limit on, and to oppose, the logic of the oppressor. That friction gave rise to new artistic insurgencies that engendered more combative modes of action in the field of art.

The friction between aesthetics and politics was at play in "border art," a term used by Luis Pazos and Juan Carlos Romero at the conference El arte como conciencia en la Argentina (Art as Consciousness in Argentina) to refer to the importation of conceptual art in Argentina. Of the many ways to think about conceptualism, Pazos and Romero chose a geopolitical category-the border-to address a broad and complex set of practices still under development in Latin America. Border art proposed artistic freedom by envisioning art as idea. It also relieved artists from the economic pressure of making works of art. At stake in the materials used-themselves precarious, in line with Latin American reality-was a set of critical actions. Conceptualism was tactical as an effective, accessible, and low-cost means of political expression.

Jorge Glusberg also articulated the production close to CAYC in terms of precarious art and the lived production conditions of Latin American artists. In 1972, CAYC sent the exhibition Hacia un perfil del arte latinoamericano (Towards a profile of Latin American Art) to the III Coltejer Biennial in Medellín. In his presentation, Glusberg sought to define his vision of Latin American art:

Latin American countries do not have an art of their own, but rather a problem born of their revolutionary movements. [...] Our artists have become aware of the needs imposed by the contexts of their nations and sought regional responses consistent with the changes proposed by the underprivileged of today, who may well be the privileged of tomorrow. (our translation). (GLUSBERG, exhib. cat. 1972.)

The Argentine critic considered the practices of the artists in the Grupo de los Trece part of what he called "ideological conceptualism," a version of conceptual art in tune with what was happening in the world's south and, more specifically, with the region's social dynamics. The Argentine geopolitical translation of international conceptual art had intense appeal in the region. It legitimized experimental practices as forms of political action in the face of a tumultuous reality marked by the rise of military regimes. ${ }^{12}$

28 Akin to ideological conceptualism and border art, the different map series Horacio Zabala made during this period alluded to the region's political upheaval. In several works, the artist used fire as an expressive element and as a metaphor for something about to explode. The maps of Latin America are burned with combustion in Seis 
imágenes del fragment 30 (Six Images of Fragment 30, 1973). In this work, the burned map along with a passage from the Greek philosopher Heraclitus indicated fire as an "eternally alive" element. The fire was at once the artist's creative fuel and an alwaysrevolutionary weapon of combat. Fire would reappear in later works, producing an atmosphere of tension in which the artist effected a double operation of art and activism. The arms of combat were poetic.

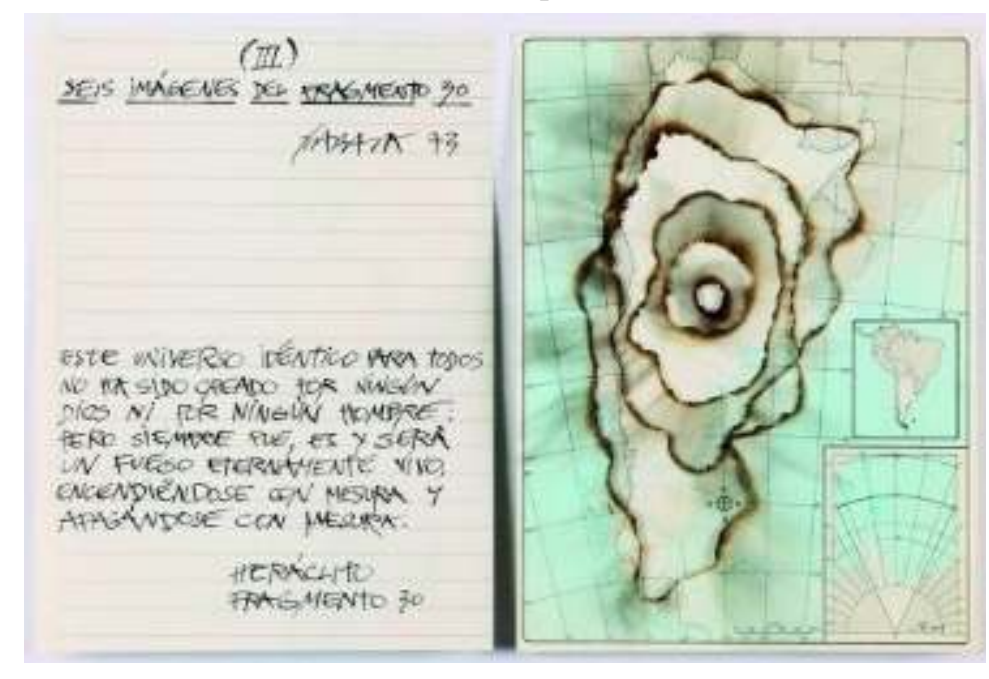

Image 4 - Horacio Zabala

Six Images of Fragment 30, 1974

Graphite on burnt paper and printed map

1973

Violence as revolutionary posture was also insinuated in works like Mira como tiemblo (Look How I Shake, 2002) and Forma y función (Form and Function, 1972-2011). The latter is a set of three empty bottles: a bottle with a flower; a bottle with gasoline; and a bottle with wine. Zabala signaled their respective functions. Gasoline to make a Molotov cocktail that can actually alter reality. Ana Longoni writes, "the same object can assume different functions according to the historical context and the will of the carrier" (LONGONI, 2013: p.35). As in his cartographic operations, here Zabala changes bottles' original function, expanding their utilitarian and poetic possibilities. 


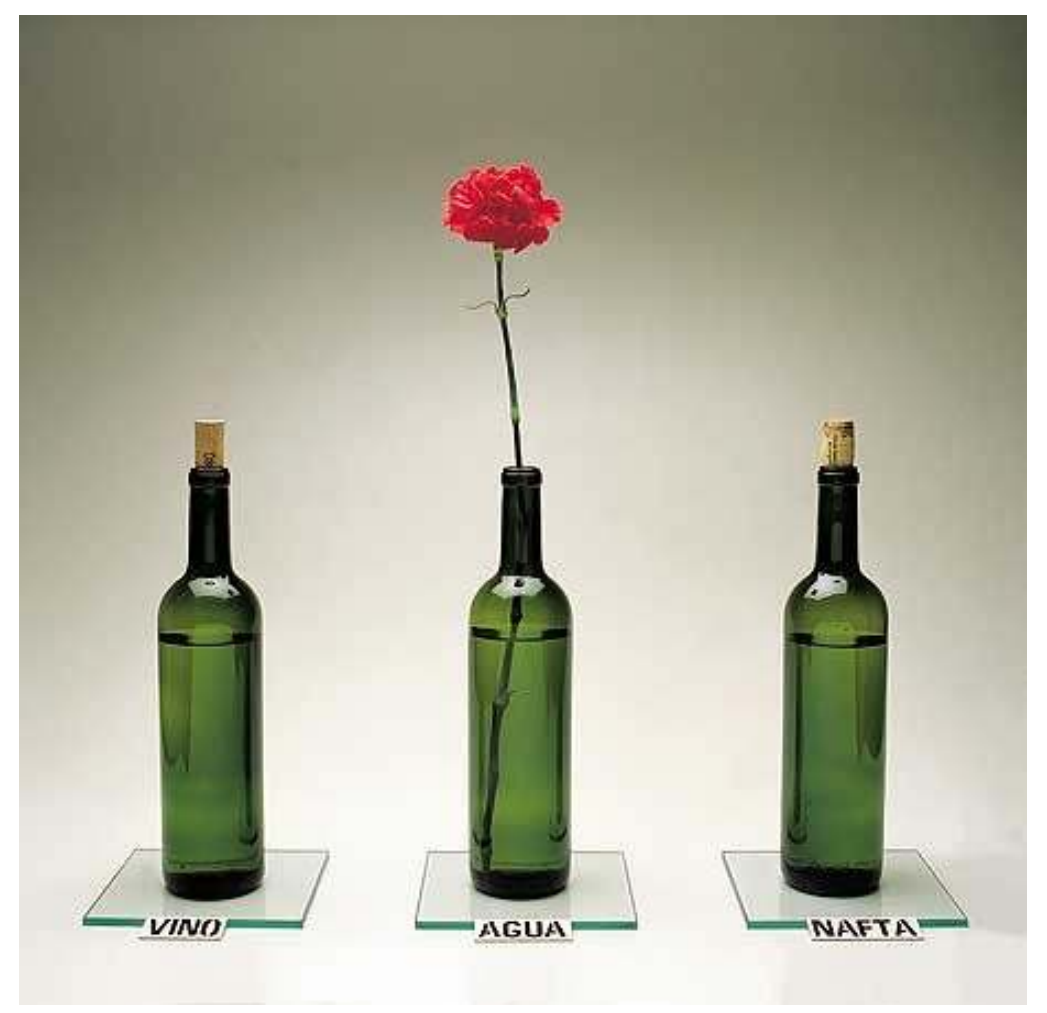

Image 5 - Horacio Zabala

Form and Function

Glass bottles, liquid, flower, text on paper

1972-2011

30 With the maps, this inversion of use was even more evident. Maps' graphic codes have, historically, been tied to a disciplinary order that systematizes and regulates geographical coordinates while also associating subjects with an exclusive territory and unique identity. Zabala twisted that logic by intervening directly on the surface of the maps, reflecting on the violence hidden in geographical conventions and their territorial delimitations.

Argentine researcher Fernando Davis has discussed Horacio Zabala's maps in terms of the poles of the opaque and the transparent. The opaque image produces leakage, a turbulence of meaning that upsets the rationality of cartographic syntax. The transparency tied to a system that neutralizes the ambiguity of signs, meanwhile, was subverted by Zabala in an open field of new geographies. "Zabala's works draw a cartography of opacity" (DAVIS, 2007: p.76).

Traditional geography fails to consider how maps are understood, revealing its own limitations as means of presenting information. Because maps are, by definition, abstractions and reductions of a reality, the Argentine artist's works raise some questions: How to represent a simultaneity of events and constant spatial disputes, showing the layers of complex historical facts in a single graphic image? The nowturbulent maps revealed how little graphic conventions managed to represent a spatial 
and social multiplicity. These other maps came close to what philosopher Fredric Jameson called "cognitive mapping": "The situational representation by the individual subject in relation to that more unrepresentable totality, which is the set of structures of society as a whole" (JAMESON, 2004).

Zabala's works affirmed a new spatial and political experience by heeding other symbolic constructions in the lived space. This new way of experiencing space was transformed by the human presence. Zabala's artistic exercise and his mobilization of the imagination to create other possible territories was in line with Milton Santos's idea of "citizenship geography" (SANTOS, 1998: p.150). The Brazilian geographer points out that in order to move from abstract citizenship to full citizenship, territorial rights and cultural rights must be taken into account.

Santos's studies often point to the imbalance arising from irregular and unjust occupation of space, mostly at the hand of capital. As part of a theoretical and geopolitical program, Santos advocated a less disparate spatial reconfiguration based on the concepts of the technosphere and the psychosphere (SANTOS, 2014: p.255). The first refers to the space of science and technology, which reproduces vertical and hierarchical relationships in an obedient and disciplined daily life. The second to the "realm of ideas, beliefs, passions and the place of producing a sense of this environment, this environment of life, providing rules for rationality or stimulating the imaginary" (SANTOS, 2014: p.256).

Zabala's conceptual maps could be associated with the psychosphere insofar as they enable new spaces for creation and meanings. Together, they constitute a counterpoint to the disciplinary experience of space by positing a territory of subjectivity and a region of border art. In Zabala's psychosphere, the desire to subvert the rational order is intensified through poetic interventions that occupy and distort territories revisados (reviwed) and censurados (censored), constructing new stories and ways of experiencing space.

Translated by Andrea Giunta

Copyedited by Jane Brodie

Bibliographie

CANCLINI, Néstor García. Culturas híbridas. São Paulo: Edusp, 2011

DAVIS, Fernando; HERRERA, Maria José; PERRET, Danielle. Horacio Zabala. Anteproyectos (1972-1978). Buenos Aires: Editorial Fundación Alón, 2007

El conceptualismo como categoría táctica. Revista Ramona, $\mathrm{n}^{\circ}$ 82. In: http://www.ramona.org.ar/node/21556.

FREIRE, Cristina. [Org.]. Walter Zanini: Escrituras Críticas. São Paulo: Annablume: MAC USP, 2013.

[Org.]. Terra Incógnita. Vol.3. Conceitualismos da América Latina no acervo do MAC USP. São Paulo: Museu de Arte Contemporânea da Universidade de São Paulo, 2015

GIUNTA, Andrea. Vanguardia, internacionalismo y política: arte argentino en los años 60 . Buenos Aires: Siglo XXI, 2008.

GLUSBERG, Jorge. Em: Hacia un perfil del arte latinoamericano. (cat. exp.), Buenos Aires, 1972. 
45 Gaglianone, 1985.

JAMESON, Fredric. Pós-modernismo: a lógica cultural do capitalismo tardio. São Paulo: Ática, 2004.

LONGONI, Ana. El medio del incendio. Violencias insurgentes en la obra de Horacio Zabala. In: DAVIS, Fernando [Org.]. Horacio Zabala, desde 1972. Sáenz Peña: Universidad Nacional Tres de Febrero, 2013.

MARCHESI, Mariana. El CAYC y el arte de sistemas como estratégia institucional. In: MARCHESI, Mariana; HERRERA, María José [Org.] Arte de sistemas: el CAYC y el proyecto de un nuevo arte regional. 1969 - 1977. Buenos Aires: Fundación OSDE, 2013.

PALADINO, Luiza Mader. Conceitualismos em Trânsito: Intercâmbios Artísticos entre Brasil e Argentina na década de 1970 - MAC USP e CAYC. Dissertação de mestrado. Programa de PósGraduação Interunidades em Estética e História da Arte, Universidade de São Paulo, São Paulo, 2015. SANTOS, Milton. O espaço do cidadão. São Paulo: Nobel, 1998. -; A natureza do espaço: Técnica e tempo. Razão e emoção. São Paulo: Edusp, 2008 SINGER, Paul. América del Sur 2006: de la geografia a la historia. In: GONZÁLEZ, Helena \& SCHMIDT, Heidulf. Democracia para una nueva sociedade (modelo para armar). Caracas: Nueva Sociedad, 1997.

ZABALA, Horacio. Dezessete questões sobre a arte. In: In: FREIRE, Cristina [Org.]. Terra Incógnita. Vol.3. Conceitualismos da América Latina no acervo do MAC USP. São Paulo: Museu de Arte Contemporânea da Universidade de São Paulo, 2015 - Entrevista com Horacio Zabala. In: FREIRE, Cristina [Org.]. Terra Incógnita. Vol.3. Conceitualismos da América Latina no acervo do MAC USP. São Paulo: Museu de Arte Contemporânea da Universidade de São Paulo, 2015

---------- CAYC al aire libre (cat. exp.), Buenos Aires, 1972.------------------. Marcel Duchamp y los restos del ready-made. Buenos Aires: Infinito, 2012.ZANINI, Walter. A arte postal na busca de uma nova comunicação internacional. In: FREIRE, Cristina. (Org.). Walter Zanini: Escrituras Críticas. São Paulo: Annablume: MAC USP, 2013.-------------------. Prospectiva 74 (cat. exp.). São Paulo: Museu de Arte Contemporânea de São Paulo - MAC USP, 1974.

\section{BIBLIOGRAPHY}

ônio e Memória. UNESP - FCLAs - CEDAP, v.3, n.1, 2007. 


\section{ENDNOTES}

1. Group created by Jorge Glusberg in 1971. Its members were Jacques Bedel, Horacio Zabala, Juan Carlos Romero, Luis Pazos, Luis Fernando Benedit, Carlos Ginzburg, Gregorio Dujovny, Alfredo Portillos, Víctor Grippo, Jorge González Mir, Vicente Marotta, Julio Teich, and Glusberg himself. In 1975, the name was changed to the Grupo CAYC.

2. A Polish director who created a theater-laboratory where all theatrical artifice was gradually abolished: makeup, light effects, sets, soundtrack, costumes etc. Doing away with all the traditional elements of theatrical language as well as the artistic act itself was an attempt to focus on total communication between the actor and the viewers to foster a complete dialogue between them.

3. Between 1969 and 1971, the conceptual exhibitions organized by Glusberg were structured around theories of communication and the use of new technologies in the creative process (I am think of the exhibitions Arte y Cibernética (Art and Cybernetics) heldat Galeria Bonino in 1969 and Arte de Sistemas (System Art), held at the Museo de Arte Moderno of Buenos Aires in 1971). In 1972, CAYC's institutional agenda expanded; its exhibitions and colloquia revolved around a regional rhetoric intended to advocate a Latin American systems art. According to Mariana Marchesi, this new orientation politicized several members of CAYC and determined the direction the Center would pursue in the coming years (MARCHESI, 2013, p.66). Examples of this new orientation are the exhibitions Hacia un perfil del arte latinoamericano (Towards a Profile of Latin American Art), presented at the III Bienal de Coltejer in Medellín in 1972, and CAYC al aire libre. Arte e Ideología (Outdoor CayC. Art and Ideology), t held in plaza Roberto Arlt in Buenos Aires that same year.

4. Letter from Walter Zanini to Jorge Glusberg. March 28, 1972. Archive of the Museu de Arte Contemporânea da Universidade de São Paulo.

5. Original version of the article A arte postal na busca de uma nova comunicação internacional published in the newspaper O Estado de S. Paulo, 1977. In: FREIRE, Cristina. (Org.). Walter Zanini: Critical Scriptures. Sao Paulo: Annablume: MAC USP, 2013.

6. Zabala wrote a book on the relationship between Marcel Duchamp, ready-mades, and contemporary art. See: ZABALA, Horacio. Marcel Duchamp y los restos del ready-made. Buenos Aires: Infinito, 2012.

7. Translator's note: Literally revised, "revisado" here suggests that the text stamped had been read by censors.

8. In the text América Del Sur: de la geografia a la historia, Brazilian economist Paul Singer addresses the historical differences between Anglo-Saxon America and Latin America. See SINGER, Paul. América Del Sur: de la geografia a la historia. In: GONZÁLEZ, Helena \& SCHMIDT, Heidulf. Democracy for a new society (model to arm). Caracas: Nueva Sociedad, 1997.

9. Letter from Luis Pazos to Walter Zanini. April 30, 1974. Archive of the Museu de Arte Contemporânea da Universidade de São Paulo . Translated from the original in Spanish.

10. The installation "Violência" was reconstructed at the 31st São Paulo Biennial in 2014.

11. Letter from Edgardo Antonio Vigo to Walter Zanini. January 15, 1975. Archive of the Museu de Arte Contemporânea da Universidade de São Paulo . Translated from the original in Spanish.

12. It is worth mentioning that Jorge Glusberg's political stance on the Argentine dictatorship was ambiguous, and he made use of controversial procedures to leverage the art clustered around CAYC on the international circuit. Glusberg had indirect ties to the Argentine military dictatorship (1976-1983), and some of CAYC's funding came from one of the largest illumination companies in Argentina, Modulor, of which Glusberg was heir. A portion of the company's profits came from military contracts-the military 
was one of its largest customers. On this subject, see: CANCLINI, Néstor García. Culturas híbridas. São Paulo: Edusp, 2011, p. 94.

\section{ABSTRACTS}

This article reflects on the maps made by artist Horacio Zabala over the course of the nineteenseventies. His production is evaluated in relation to institutions that supported experimental artists from Latin America: the Museu de Arte Contemporânea da Universidade de São Paulo and the Centro de Arte y Comunicación in Buenos Aires. Both entities were instrumental to establishing a transnational conceptual art circuit through specific strategies, such as the exchange of artists and art exhibitions. In order to analyze this institutional network of which Zabala formed part, this paper looks to both primary and bibliographic sources.

Este artigo apresenta uma reflexão sobre os mapas realizados pelo artista Horacio Zabala, ao longo da década de 1970. Sua produção é avaliada a partir de uma importante rede de instituições que amparou artistas experimentais da América Latina: o Museu de Arte Contemporânea da Universidade de São Paulo e o Centro de Arte y Comunicación, de Buenos Aires. Ambas as entidades estabeleceram um circuito transnacional de arte conceitual, ao constituir estratégias específicas, como o intercâmbio de artistas e exposições de arte. Para analisar essa trama institucional da qual Zabala fez parte, este trabalho parte do cruzamento de fontes primárias e bibliográficas como procedimento metodológico de pesquisa.

\section{INDEX}

Keywords: Horacio Zabala; CAYC; MAC USP; Conceptual art; Mail Art.

Palavras-chave: Horacio Zabala; CAYC; MAC USP; Arte Conceitual; Arte Postal

\section{AUTHOR}

\section{LUIZA MADER PALADINO}

Doctoral candidate at the Inter-unit Graduate Program in Aesthetics and Art History at USP. She is a member of the GEACC - Grupo de Estudos em Arte Conceitual e Conceitualismos housed at the Museum and coordinated by Professor Dra. Cristina Freire. 